\title{
PEMURNIAN KITOSAN HASIL FERMENTASI LIMBAH CANGKANG KEPITING MENGGUNAKAN PELARUT ASAM ASETAT
}

\author{
Holis Muhlis ${ }^{1}$, Alfariz Dwi Pradana ${ }^{1}$, Unung Leoanggraini ${ }^{1} *$ \\ ${ }^{1}$ Jurusan Teknik Kimia, Politeknik Negeri Bandung \\ *E-mail: ununglz@yahoo.com
}

\begin{abstract}
ABSTRAK
Kitosan dapat diperoleh melalui proses fermentasi cangkang kepiting yang dilakukan secara sekuensial menggunakan bakteri Lactobacillus acidophilus dan Bacillus subtilis. Satu upaya peningkatan kualitas produk kitosan dapat dilakukan dengan proses pemurnian melalui metode ekstraksi padat cair dengan pelarut asam. Tujuan penelitian ini adalah untuk mengetahui pengaruh variasi rasio kitosan hasil fermentasi dengan pelarut asam asetat $1 \%$ terhadap tingkat kemurnian kitosan yang dihasilkan. Proses pemurnian kitosan dilakukan dengan variasi rasio kitosan hasil fermentasi terhadap pelarut asam asetat 1\% pada perbandingan 1:60, 1:80, 1:100 dan 1:120 (b/v). Hasil penelitian menunjukkan bahwa kondisi optimum proses pemurnian kitosan diperoleh pada rasio 1:60 dengan nilai kadar air, kadar abu, kadar protein, kelarutan dalam asam asetat $1 \%$ dan derajat deasetilasi berturut-turut sebesar $24,3 \%, 58,6 \%, 9,2 \%, 93,3 \%$ dan $75,5 \%$. Nilai kadar protein, kelarutan dalam asam asetat $1 \%$ dan derajat deasetilasi sudah memenuhi standar SNI No. 7949:2013, namun nilai kadar air dan kadar abu belum memenuhi standar SNI No. 7949:2013.
\end{abstract}

Kata Kunci: Asam Asetat, Cangkang Kepiting, Fermentasi Sekuensial, Kitosan, Pemurnian.

\begin{abstract}
Chitosan is obtained through the crab shell fermentation process which is carried out sequentially using Lactobacillus acidophilus and Bacillus subtilis bacteria. One of the efforts to improve the quality of chitosan products can be done with a purification process through the solid-liquid extraction method with acid solvent. The purpose of work was to determine the effect of variations in the ratio of fermented chitosan with $1 \%$ acetic acid solvent on the level of purity of the chitosan produced. The chitosan purification process was carried out by varying the ratio of fermented chitosan to $1 \%$ acetic acid solvent at a ratio of 1:60, 1:80, 1:100 and 1:120 (w/v). The results showed that the optimum condition of the chitosan purification process was obtained at a ratio of 1:60 with the values of water content, ash content, protein content, solubility in acetic acid $1 \%$ and the degree of deacetylation respectively $24.3 \%, 58.6 \%, 9.2 \%, 93.3 \%$ and $75.5 \%$. The value of protein content, solubility in $1 \%$ acetic acid and the degree of deacetylation have met the standard of SNI No. 7949:2013, but the value of water content and ash content does not meet the standard of SNI No. 7949:2013.
\end{abstract}

Keywords: Acetic Acid, Crab Shell, Sequential Fermentation, Chitosan, Purification.

\section{PENDAHULUAN}

Indonesia merupakan negara maritim dengan potensi perikanan berlimpah namun belum dimanfaatkan secara maksimal (Meliala, 2016). Salah satu potensi laut Indonesia adalah kepiting dengan perolehan mencapai 58 ribu ton pada tahun 2020 (Statistik-KKP, 2020). Konsumsi kepiting berpotensi menghasilkan limbah sebesar 40-60\% dari total berat kepiting (Azizi dkk, 2020). Limbah ini jika tidak ditangani 
dengan baik akan mencemari lingkungan karena aktivitas mikroorganisme dapat mempercepat proses pembusukan (Asni dkk, 2014).

Cangkang kepiting mengandung senyawa kitin yang memiliki nilai jual tinggi (Asni dkk, 2014). Kandungan kitin dalam cangkang kepiting adalah sebesar $71 \%$ (Harianingsih, 2010). Kitin merupakan komponen karbohidrat utama pada eksoskeleton krustasea yang berfungsi sebagai komponen penyokong dan pelindung (Hahn, 2020). Polimer kitin merupakan golongan polisakarida yang tersusun atas $\beta(1-4)$-linked $\mathrm{N}$ acetyl-D-glucosamine (Dutta, 2014). Kitosan merupakan kopolimer Dglukosamin dan $\mathrm{N}$-asetil-D-glukosamin dengan ikatan $\beta$-(164), diperoleh melalui proses alkali atau deasetilasi enzimatik dari polisakarida kitin. Kitosan memiliki nama kimia Poly d-glukosamin $(\beta(1-4)$ 2-amino-2-deoksi-D-glucose) (Zulfahmi \& Taufan, 2010). Perbedaan antara kitin dan kitosan terletak pada gugus fungsinya, kitin memiliki gugus asetil ($\mathrm{CH}_{3} \mathrm{CO}$ ) sedangkan kitosan memiliki gugus amina (-NH) (Pratiwi, 2014).

Proses sintesis kitosan dari cangkang kepiting dapat dilakukan secara biologis dengan metode fermentasi yang memanfaatkan aktivitas mikroorganisme meliputi proses deproteinasi, demineralisasi, dan deasetilasi. Sintesis kitosan dengan metode fermentasi dapat dilakukan dengan menggunakan bakteri L. acidophilus (Andriyana, 2017) dan B. subtilis secara simultan (Nurdiana \& Rahman, 2018).

Deproteinasi merupakan proses pemecahan protein yang terdapat dalam limbah (Harjanti, 2014). Proses deproteinasi dilakukan oleh enzim protease yang dihasilkan oleh bakteri seperti Seratia marcescens, Aspergillus sp dan Bacillus sp (Synowiecki \& AlKhateeb, 2003). Demineralisasi merupakan proses pengurangan mineral dalam suatu bahan. Proses demineralisasi dilakukan oleh asam laktat yang dihasilkan oleh bakteri seperti Aspergillus niger, Penicillium notatum, Lactobacillus. sp, Bacillus sp, serta bakteri penghasil asam laktat lainnya (Arbia dkk, 2013). Deasetilasi merupakan proses perubahan gugus fungsi asetil pada kitin menjadi gugus amin (Afifah dkk, 2017). Proses deasetilasi secara biologis melibatkan enzim kitin deasetilase (Yadav dkk, 2019).

Sintesis kitosan dengan metode fermentasi secara simultan telah dilakukan oleh (Nurdiana \& Rahman, 2018). Produk kitosan hasil penelitian tersebut memiliki nilai kadar abu yang cukup tinggi di atas baku mutu SNI No. 7949:2013. Kadar abu menunjukkan kandungan pengotor berupa komponen anorganik atau mineral pada suatu bahan (Kaderi, 2015). Baku mutu kitosan menurut SNI No. 7949:2013 disajikan dalam Tabel 1.

Tabel 1. Karakteristik Kitosan Menurut Baku Mutu SNI No. 7949:2013 (SNI, 2018)

\begin{tabular}{lc}
\hline Karakteristik & $\begin{array}{c}\text { Baku Mutu SNI } \\
(\%)\end{array}$ \\
\hline Kadar Air & Maks 12 \\
Kadar Abu & Maks 5 \\
Derajat & Min 75 \\
Deasetilasi & Maks 31,2 \\
Kadar Protein & \\
\hline
\end{tabular}

Salah satu upaya untuk meningkatkan baku mutu kitosan yaitu dengan proses pemurnian melalui pelarutan asam. Asam yang dapat melarutkan kitosan kebanyakan asam organik seperti asam asetat dan asam laktat. Asam anorganik seperti $\mathrm{HCl}$ dan $\mathrm{HNO}_{3}$ dapat melarutkan kitosan pada konsentrasi tertentu. Kitosan juga sedikit larut dalam larutan $\mathrm{H}_{3} \mathrm{PO}_{4}$.

Proses pemurnian dapat dilakukan dengan menambahkan suatu senyawa pembentuk senyawa kompleks protein 
dan mineral dalam kondisi $\mathrm{pH}$ optimum sehingga membentuk endapan kitosan yang tidak larut dalam air dan senyawa kompleks yang larut dalam air. Metode pemurnian lainnya adalah dengan melarutkan kitosan dalam suatu pelarut sehingga membentuk larutan kitosan antara. Larutan ini kemudian ditambahkan dengan suatu senyawa dalam kondisi $\mathrm{pH}$ optimum untuk membentuk endapan kitosan murni (United States of America Paten No. US 6,896,809 B2, 2005).

\section{METODOLOGI}

Penelitian dilakukan dalam 2 tahap yaitu proses fermentasi dan proses pemurnian.

\section{Proses Fermentasi}

Bahan baku yang digunakan pada proses fermentasi berupa serbuk cangkang kepiting dengan ukuran 0,2 $\mathrm{mm}$. Analisis bahan baku dilakukan terlebih dahulu meliputi analisis kadar air, kadar abu, kadar protein dan kelarutan. Bakteri yang digunakan adalah L. acidophilus yang telah dibiakkan dalam media Panthotenate selama 24 jam pada suhu $37^{\circ} \mathrm{C}$ dan $B$. subtilis yang dibiakkan dalam media Kaldu Nutrisi selama 8 jam pada suhu $37^{\circ} \mathrm{C}$.

Serbuk limbah cangkang kepiting difermentasi oleh bakteri L. acidophilus. Media fermentasi berupa 500 gram serbuk limbah cangkang kepiting, sukrosa $15 \%(\mathrm{~b} / \mathrm{b})$ dan air dengan rasio 1,5:1 terhadap bahan baku. Media fermentasi diatur pada $\mathrm{pH} 6$ dengan penambahan asam asetat glasial. Penambahan inokulum sebanyak $10 \%$ (v/b) dan proses fermentasi dilakukan pada suhu $37^{\circ} \mathrm{C}$ selama 96 jam dengan kecepatan pengadukan $120 \mathrm{rpm}$ dengan menggunakan incubator shaker (Andriyana, 2017). Setelah proses fermentasi berakhir, dilakukan recovery produk dengan pencucian, sentrifugasi, penyaringan dan pengeringan.

Produk hasil fermentasi oleh bakteri L. acidophilus kemudian difermentasi kembali oleh bakteri $B$. subtilis. Media fermentasi berupa 400 gram produk fermentasi pertama, sukrosa $2 \%(\mathrm{~b} / \mathrm{b})$ dan air dengan rasio 1,63:1 terhadap bahan baku. Media fermentasi diatur pada $\mathrm{pH} 5$ dengan penambahan asam asetat glasial. Penambahan inokulum sebanyak 20\% (v/b) dan proses fermentasi dilakukan pada suhu $40^{\circ} \mathrm{C}$ selama 18 jam dengan kecepatan pengadukan 120 rpm (Nurdiana \& Rahman, 2018). Setelah proses fermentasi berakhir, dilakukan recovery produk dengan pencucian, sentrifugasi, penyaringan dan pengeringan.

\section{Proses Pemurnian}

Proses pemurnian dilakukan pada 30 gram produk kitosan hasil fermentasi kedua yang dilarutkan dalam larutan asam asetat $1 \%$ dengan variasi rasio kitosan dengan palarut sebesar 1:60, 1:80, 1:100 dan 1:120. Larutan kitosan kemudian diaduk dengan kecepatan 120 rpm selama 16 jam. Selanjutnya larutan kitosan disentrifugasi dengan kecepatan $4500 \mathrm{rpm}$ selama 10 menit. Supernatan yang dihasilkan dididihkan selama 15 menit agar terjadi denaturasi protein. Larutan kitosan kemudian disentrifugasi kembali dengan kecepatan $4500 \mathrm{rpm}$ selama 10 menit serta dilakukan penyaringan. Supernatan yang dihasilkan ditambahkan larutan $\mathrm{NaOH}$ $1 \mathrm{~N}$ sampai $\mathrm{pH} 9$ sehingga terbentuk presipitat kitosan. Larutan kemudian disentrifugasi dengan kecepatan 4500 rpm selama 10 menit dan dikeringkan pada suhu $55^{\circ} \mathrm{C}$ (Nasti dkk, 2009).

Analisis produk kitosan dilakukan terhadap produk hasil fermentasi serta produk hasil pemurnian. Analisis yang dilakukan meliputi kadar air, kadar abu, 
kadar protein, kelarutan, derajat deasetilasi dan rendemen.

\section{PEMBAHASAN \\ Proses Fermentasi}

Karakteristik bahan baku dan kitosan hasil fermentasi oleh bakteri L. acidophilus dan B. subtilis disajikan dalam Tabel 2.

Tabel 2. Karakteristik Bahan Baku

\begin{tabular}{|c|c|c|c|}
\hline Karakteristik & $\begin{array}{c}\text { Bahan Baku } \\
\text { Serbuk } \\
\text { Cangkang } \\
\text { Kepiting } \\
(\%)\end{array}$ & $\begin{array}{c}\text { Fermentasi } \\
L . \\
\text { acidophilu } \\
s \\
(\%) \\
\end{array}$ & $\begin{array}{c}\text { Fermentasi } \\
\text { B. subtilis } \\
\quad(\%)\end{array}$ \\
\hline Kadar Air & 6,0 & 7,0 & 6,0 \\
\hline Kadar Abu & 36,1 & 34,4 & 35,6 \\
\hline $\begin{array}{l}\text { Kadar } \\
\text { Protein }\end{array}$ & 42,3 & 40,1 & 36,5 \\
\hline $\begin{array}{l}\text { Derajat } \\
\text { Deasetilasi }\end{array}$ & & 85,3 & 96,6 \\
\hline Rendemen & & 85,8 & 90,6 \\
\hline
\end{tabular}

Karakteristik bahan baku digunakan untuk mengetahui tingkat pengurangan kadar abu dan kadar protein serta sebagai acuan keberhasilan proses pemurnian.

Berdasarkan Tabel 2, proses fermentasi oleh bakteri L. acidophilus cenderung pada proses deproteinasi dan proses demineralisasi secara simultan. Bakteri L. acidophilus menghasilkan enzim protase serta asam laktat selama proses fermentasi. Asam laktat akan memecah ikatan peptida pada protein yang terikat secara kovalen menjadi peptida sederhana dan asam amino (Andriyana, 2017), sehingga terjadi penurunan nilai kadar protein dari $42,3 \%$ menjadi $40,1 \%$. Penurunan kadar abu dari $36,1 \%$ menjadi $34,4 \%$ terjadi karena adanya reaksi asam laktat dengan kalsium karbonat dalam serbuk cangkang kepiting menjadi kalsium laktat.

Proses fermentasi oleh bakteri $B$. subtilis cenderung pada penurunan kadar protein serta pelepasan mineral hasil metabolisme. Bakteri B. subtilis menghasilkan enzim protease (Hajji dkk, 2015) yang memiliki kemampuan untuk memecah protein menjadi molekul yang lebih sederhana, sehingga terjadi penurunan kadar protein dari 40,1\% menjadi $36,5 \%$. Kenaikan kadar abu dari $34,4 \%$ menjadi $35,6 \%$ terjadi karena adanya pelepasan mineral akibat adanya aktivitas bakteri $B$. subtilis. Mineral yang didegradasi selama proses fermentasi masih berada pada produk tetapi sudah tidak terikat dengan produk.

Keterikatan mineral dengan produk berkaitan dengan nilai Derajat Deasetilasi. Nilai Derajat Deasetilasi yang tinggi menunjukkan bahwa ikatan mineral dalam kitosan semakin sedikit. Nilai Derajat Deasetilasi kitosan hasil fermentasi oleh bakteri L. acidophilus adalah sebesar $85,3 \%$ dan hasil fermentasi oleh bakteri $B$. subtilis adalah sebesar 96,6\%. Kenaikan nilai derajat deasetilasi disebabkan oleh adanya aktivitas enzim kitinase yang dihasilkan oleh bakteri B. subtilis. Enzim ini dapat merubah gugus hidroksil pada kitin menjadi gugus amin (Pratiwi, 2014).

Rendemen yang dihasilkan pada proses fermentasi oleh bakteri $L$. acidophilus adalah sebesar $85,8 \%$ dan proses fermentasi oleh bakteri $B$. subtilis adalah sebesar $90,6 \%$.

\section{Proses Pemurnian \\ Karakteristik Hasil Pemurnian}

Pengukuran karakteristik produk dilakukan pada dua sampel yang berbeda, yaitu pada produk kitosan hasil pemurnian dan bahan baku yang telah dilakukan proses pemurnian dengan kondisi operasi pemurnian yang sama. Pengukuran karakteristik produk dilakukan pada kondisi oprasi yang sama.

Nilai kadar air, kadar abu dan kadar protein produk kitosan dan bahan baku yang telah melalui proses 
pemurnian dapat dilihat pada Gambar 1 dan 2.

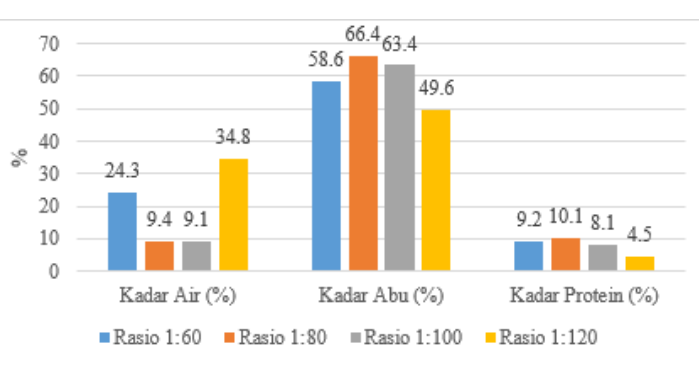

Gambar 1. Karakteristik Kitosan Hasil Pemurnian pada Berbagai Variasi Rasio Sampel dengan Pelarut Asam Asetat

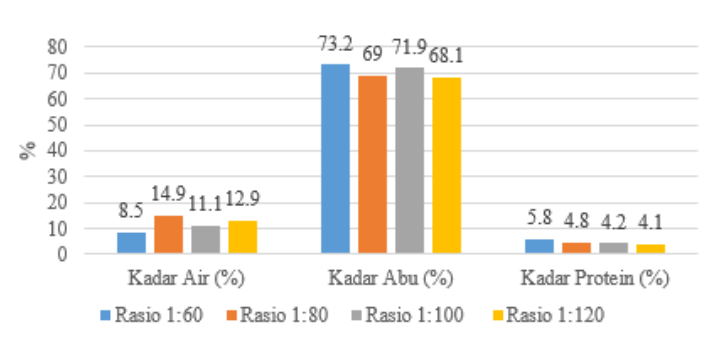

Gambar 2. Karakteristik Bahan Baku Hasil Pemurnian pada Berbagai Variasi Rasio Sampel dengan Pelarut Asam Asetat

Tinggi rendahnya kadar air berkaitan dengan keberhasilan proses pengeringan produk, mencakup jumlah dan luas permukaan tempat pengeringan kitosan. Mengacu pada standar mutu SNI No. 7949:2013, kadar air kitosan yang ditunjukkan pada Gambar 1, yang memenuhi standar SNI No. 7949:2013 yaitu pada variasi rasio 1:80 dan 1:100 yang besarnya berturut-turut $9,4 \%$ dan $9,1 \%$. Kadar air produk kitosan pada variasi rasio 1:60 dan 1:120 yang besarnya berturut-turut $24,3 \%$ dan $34,8 \%$ tidak memenuhi standar SNI No. 7949:2013 maksimal sebesar 12\%. Nilai kadar air berhubungan dengan kemampuan tumbuh mikroorganisme dalam suatu bahan. Semakin rendah kadar air kitosan, maka kitosan berada pada kondisi dapat menekan pertumbuhan mikroorganisme yang dapat merusak produk kitosan.
Nilai kadar abu produk kitosan yang ditunjukkan pada Gambar 1 tidak memenuhi kriteria standar mutu SNI No. 7949:2013 yaitu maksimal sebesar 5\%. Peningkatan kadar abu dalam produk terjadi karena adanya mineral yang larut dalam asam. Selain itu, tidak dilakukannya pencucian pada produk kitosan juga berpotensi naiknya nilai kadar abu produk kitosan. Selain itu, proses presipitasi kitosan oleh larutan $\mathrm{NaOH} 1 \mathrm{~N}$ akan meninggalkan lapisan logam $\mathrm{Na}$ pada permukaan kitosan, sehingga ketika dilakukan proses pengeringan, lapisan logam $\mathrm{Na}$ akan mengendap menjadi partikel logam sehingga meningkatkan nilai kadar abu produk kitosan. Nilai kadar abu bahan baku yang telah dilakukan proses pemurnian juga menunjukkan nilai yang tinggi. Kadar abu bahan baku yang telah melalui proses pemurnian lebih tinggi dari kadar abu kitosan hasil pemurnian. Tingginya nilai kadar abu bahan baku, selain dari adanya lapisan logam $\mathrm{Na}$, juga pada produknya sendiri masih mengikat logam karena belum melalui proses fermentasi.

Kadar protein produk kitosan yang ditunjukkan Gambar 1 telah memenuhi standar mutu SNI No. 7949:2013, dengan nilai dibawah $31,2 \%$ untuk semua variasi rasio sampel terhadap pelarut asam asetat. Senyawa protein yang terikat dalam kitosan akan terlepas dengan adanya perlakuan asam, terlebih dilakukan pada suhu tinggi. Nilai kadar protein produk kitosan terendah yaitu pada variasi rasio 1:120 sebesar 4,5\% Perbandingan kadar protein bahan baku dan kitosan yang ditunjukkan pada Gambar 1 dan 2, menunjukkan bahwa kadar protein bahan baku lebih rendah dari kadar protein kitosan. Rendahnya kadar protein pada bahan baku mengindikasikan bahwa proses denaturasi protein dengan pendidihan, lebih tinggi pada bahan baku. 
Berdasarkan hasil pengamatan visual, larutan bahan baku lebih mudah mendidih dan kenaikan temperatur lebih cepat dibandingkan dengan larutan kitosan. Selain itu, kehadiran gugus amin pada kitosan berpotensi untuk menambah kandungan protein pada produk kitosan.

\section{Kelarutan, Derajat Deasetilasi, dan Rendemen}

Nilai derajat deasetilasi kitosan hasil fermentasi dan kitosan yang telah melalui proses pemurnian serta perbandingannya dengan baku mutu SNI No. 7949:2013 ditunjukkan pada Gambar 3. Nilai kelarutan berbagai sampel mulai dari cangkang kepiting, kitosan hasil fermentasi, sampai dengan kitosan yang telah melalui proses pemurnian ditunjukkan pada Gambar 4. Nilai rendemen kitosan dan bahan baku hasil pemurnian pada berbagai variasi rasio sampel terhadap pelarut asam asetat ditunjukkan pada Gambar 5.

Nilai Derajat Deasetilasi kitosan hasil fermentasi oleh bakteri $L$. acidophilus yang ditunjukkan pada Gambar 3 adalah sebesar 85,31\%. Nilai Derajat Deasetilasi kitosan meningkat dengan dilakukannya proses fermentasi lanjutan oleh bakteri B. subtilis menjadi 96,6\%. Hal ini berkaitan dengan enzim kitinase yang dihasilkan oleh bakteri $B$. subtilis berguna untuk menghilangkan gugus asetil kitin sehingga akan meningkatkan nilai Derajar Deasetilasi. Nilai Derajat Deasetilasi menunjukkan adanya penurunan pada kebanyakan produk kitosan yang telah melalui proses pemurnian. Nilai derajat deasetilasi tertinggi diperoleh pada variasi rasio 1:100 yaitu sebesar $96,6 \%$. Perubahan atau kenaikan rasio tidak berpengaruh secara signifikan terhadap nilai derajat deasetilasi yang dihasilkan. Nilai derajat deasetilasi pada masing-masing sampel berada di atas baku mutu SNI No. 7949:2013 yaitu sebesar 75\%.

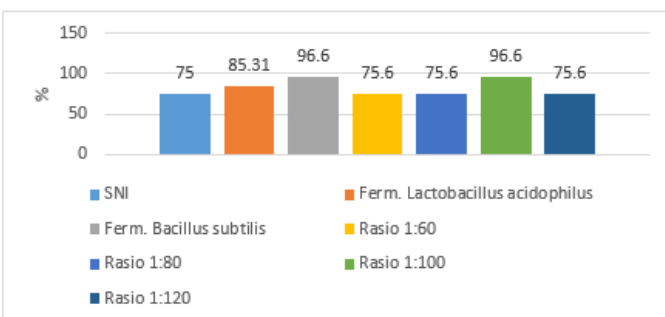

Gambar 3. Nilai Derajat Deasetilasi Kitosan Hasil Fermentasi dan Proses Pemurnian pada Berbagai Rasio Sampel dengan Pelarut Asam Asetat serta Perbandingannya dengan SNI No. 7949:2013

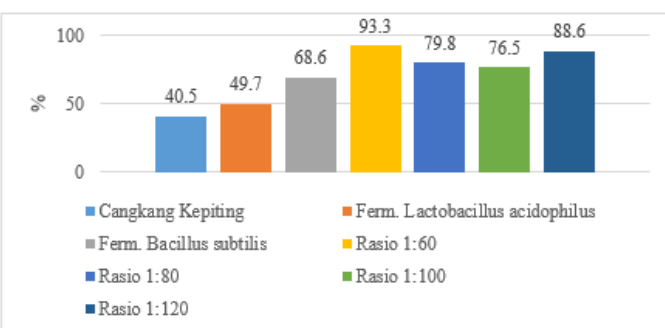

Gambar 4. Kelarutan Cangkang Kepiting, Kitosan Hasil Fermentasi dan Kitosan yang Telah Melalui Proses Pemurnian pada Berbagai Variasi dalam Larutan Asam Asetat 1\%.

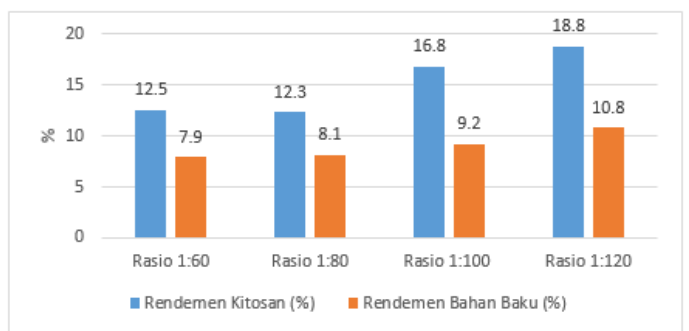

Gambar 5. Nilai Rendemen Kitosan dan Bahan Baku Hasil Pemurnian pada Bebagai Variasi Rasio Sampel dengan Pelarut Asam Asetat

Kelarutan berbagai sampel yang ditunjukkan pada Gambar 4, menunjukkan adanya peningkatan kelarutan seiring dengan bertambahnya perlakuan. Nilai kelarutan kitosan berbanding lurus dengan kualitasnya. Kehadiran gugus karboksil dalam asam asetat akan meningkatkan interaksi hidrogen antara gugus karboksil dan gugus amin dalam kitosan sehingga akan 
memudahkan proses pelarutan kitosan. Naiknya tingkat kelarutan pada berbagai proses yang berkelanjutan mengindikasikan bahwa tingkat kemurnian kitosan juga semakin tinggi. Perubahan atau kenaikan rasio tidak berpengaruh secara signifikan terhadap kelarutan kitosan dalam asam asetat $1 \%$. Hal ini berkaitan dengan konsistensi tingkat kelarutan kitosan pada berbagai variasi rasio menunjukkan nilai yang tidak jauh berbeda satu dengan lainnya. Nilai kelarutan tertinggi yaitu pada rasio 1:60 dengan kelarutan sebesar 93,3\%.

Rendemen merupakan tingkat konversi pemurnian secara keseluruhan. Nilai rendemen yang tinggi menunjukkan banyaknya jumlah kitosan terlarut dalam asam asetat. Semakin tinggi nilai rendemen, maka semakin banyak kitosan terlarut serta menunjukkan tingginya kandungan kitosan dalam produk tersebut. Nilai rendemen yang ditunjukkan pada Gambar 5 tidak sesuai dengan penelitian (Nasti dkk, 2019) yaitu sebesar 86\%. Rendahnya nilai rendemen dapat disebabkan oleh rendahnya konversi kitosan pada proses fermentasi yang mengakibatkan kitosan yang terlarut dalam asam asetat sedikit. Aktivitas mikroorganisme dalam proses fermentasi dan kondisi operasi menjadi faktor penentu keberhasilan proses fermentasi. Rendemen yang dihasilkan berada pada kisaran $12 \%$ sampai $18 \%$. Nilai rendemen tertinggi diperoleh pada variasi rasio 1:120 sebesar $18,8 \%$ dan rendemen terendah diperoleh pada rasio 1:80 yaitu sebesar $12,3 \%$.

\section{KESIMPULAN}

Proses pemurnian yang menghasilkan produk kitosan dengan kemurnian tinggi yaitu pada rasio kitosan terhadap pelarut asam asetat 1\% sebesar 1:60 dengan nilai kadar air, kadar abu, kadar protein, kelarutan dalam asam asetat $1 \%$ dan derajat deasetilasi berturut-turut sebesar $24,3 \%$, $58,6 \%, 9,2 \%, 93,3 \%$ dan $75,5 \%$. Nilai kadar protein, kelarutan dalam asam asetat $1 \%$ dan derajat deasetilasi sudah memenuhi standar SNI No. 7949:2013, namun nilai kadar air dan kadar abu belum memenuhi standar SNI No. 7949:2013.

\section{DAFTAR RUJUKAN}

Afifah, K. N., Koentjoro, M. P., \& Prasetyo, E. N. (2017). Produksi Kitosan Secara Enzimatik oleh Bacillus Sampah Perikanan. Proceeding Biology Education Conference, 14.

Andriyana, I. (2017). Ekstraksi Kitin dari Limbah Cangkang Kepiting Secara Fermentasi Menggunakan Bakteri Lactobacillus Achidophilus. Bandung: Politeknik Negeri Bandung.

Arbia, W., Leila, A., Lydia, A., \& Abdeltif, A. (2013). Chitin Extraction from Crustacean Shells Using Biological Methods. Food Technol, Biotechnol, 51.

Asni, N., Saadilah, M. A., \& Saleh, D. (2014). Optimalisasi Sintesis Kitosan dari Cangkang Kepiting Sebagai Adsorben Logam Berat $\mathrm{Pb}$ (II). Jurnal Fisika dan Aplikasinya, Vol. 15 No.1.

Azizi, A., Fairus, S., \& Mihardja, E. J. (2020). Pemanfaatan Limbah Cangkang Rajungan sebagai Bahan Kitin dan Kitosan di Purchasing Crap Unit Eretan "Atul Gemilang", Indramayu. Jurnal Solma, 09, No. 02 pp. 411 419.

Dutta, J. (2014). Isolation, Purification, and Nanotechnological Applications of Chitosan. Polysaccharides. 
Hahn, T., Tafi, E., Paul, A., \& Salvia, R. (2020). Current State of Chitin Purification and Chitosan Production from Insects. J Chem Technol Biotechnol, 95.

Hajji, S., Ghorbel-Bellaj, O., Younes, I., Jellouli, K., \& Moncef, N. (2015). Chitin Extraction From Crab Shells by Bacillus Bacteria. Biological Activities of Fermented Crab Supernatants. International Journal of Biological Macromolecules.

Harianingsih. (2010). Pemanfaatan Limbah Cangkang Kepiting Menjadi Kitosan Sebagai Bahan Pelapis ( Coater) pada Buah Stroberi. Semarang: Universitas Dipenogoro.

Harjanti, R. S. (2014). Kitosan dari Limbah Udang sebagai Bahan Pengawet Ayam Goreng. Jurnal Rekayasa Proses, 8.

Kaderi, H. (2015, Oktober 12). Arti Penting Abu Pada Bahan Olahan. Dipetik Maret 18, 2021, dari Balai Penelitian Lahan Rawa: http://balittra.litbang.pertanian.g o.id/index.php?option=comconte nt $\&$ view $=$ article $\& i d=1676 \&$ Ite $\operatorname{mid}=10$

Meliala, A. (2016, Juni 15). Potensi Laut Indonesia Belum Dimanfaatkan Secara Optimal. Dipetik Februari 22, 2021, dari Pikiran Rakyat: https://www.pikiranrakyat.com/nasional/pr01258003/potensi-lautindonesia-belum-dimanfaatkansecara-optimal-371905

Nasti, A., Zaki, N. M., Leonardis, P. d., Ungphaiboon, S., Sansongsak, P., Rimoli, M. G., \& Tirelli, N. (2009). Chitosan/TPP and Chitosan/TPP-hyaluronic Acid Nanoparticles: $\quad$ Systematic Optimisation of the Preparative Process and Preliminary
Biological Evaluation. Pharmaceutical Research, 26.

Nurdiana, A., \& Rahman, I. N. (2018). Fermentasi Limbah Cangkang Kepiting untuk Menghasilkan Kitosan Menggunakan Lactobacillus acidophilus dan Bacillus subtilis secara Sekuensial. Bandung: Politeknik Negeri Bandung.

Patent, U. S. (2005, Mei 24). United States of America Paten No. US 6,896,809 B2.

Pratiwi, R. (2014). Manfaat Kitin dan Kitosan Bagi Kehidupan Manusia. Oseana, XXXIX.

SNI. (2018). SNI Produk Perikanan Non-Pangan.

Statistik-KKP. (2020). Data Ekspor Impor. Dipetik Maret 25, 2020, dari Statistik-KKP: https://statistik.kkp.go.id/home.p $\mathrm{hp} ? \mathrm{~m}=\mathrm{eksim} \& \mathrm{i}=211 \#$ panelfooter

Synowiecki, J., \& Al-Khateeb, N. A. (2003). Production, Properties, and Some New Applications of Chitin And Its Derivatives. Critical Reviews in Food Science and Nutrition.

Yadav, M., Goswami, P., Paritosh, K., Kumar, M., \& Pareek, N. (2019). Seafood Waste: A Source for Preparation of Commercially Employable Chitin/Chitosan Materials. Bioresources and Bioprocessing.

Zulfahmi, \& Taufan, M. R. (2010). Pemanfaatan Limbah Kulit Udang sebagai Bahan Anti Rayap (Bio-termitisida) pada Bangunan Berbahan Kayu. Semarang: Universitas Dipenogoro. 